\title{
ANALISIS SISTEM PENGELOLAAN DANA DESA BERDASARKAN REGULASI KEUANGAN DESA
}

\author{
Siti Khoiriah*, Utia Meylina \\ Fakultas Hukum Universitas Lampung \\ Jln. Soemantri Brojo Negoro Nomor 1, Gedung Meneng, Bandar Lampung, 35145 \\ siti.khoiriah@fh.unila.ac.id
}

\begin{abstract}
Village is the smallest entity in the government of Indonesia that is recognized and respected in conformity based on the constitution. The village has been through a long history of regulation that finally the regulation of the village is specifically regulated in Law No. 6 of 2014 on Villages. The regulation brought the village into a new phase and brought new hopes for society and village governance that had a close impact on village finances in particular with the village fund management system. Using a Juridical-normative approach, this study concludes that Indonesia has had significant regulation related to the management of village funds from the village fund management stage to the village fund management oversight system. Stages of management and supervision of village fund management as contained in legislation will have a positive potential in the implementation of accountability administration or public accountability of village administration.
\end{abstract}

Keywords: regulation, village financial

\begin{abstract}
Abstrak
Desa merupakan entitas terkecil dalam pemerintahan Indonesia yang diakui dan dihormati berrsadarkan konstitusi. Desa telah melalui sejarah pengaturan yang panjang yang akhirnya pengaturan tentang desa secara khusus diatur dalam Undang-Undang Nomor 6 Tahun 2014 tentang Desa. Pengaturan tersebut membawa desa memasuki babak baru dan membawa harapanharapan baru bagi kehidupan kemasyarakatan dan pemerintahan desa yang berdampak erat kepada keuangan desa terkhusus terkait dengan sistem pengelolaan dana desa. Dengan menggunakan pendekatan yuridis-normatif, penelitian ini menyimpulkan bahwa Indonesia telah memiliki regulasi signifikan terkait dengan pengelolaan dana desa mulai dari tahapan pengelolaan dana desa sampai kepada sistem pengawasan pengelolaan dana desa. Tahapan pengelolaan dan pengawasan pengelolaan dana desa seperti yang terdapat dalam peraturan perundang-undangan akan berpotensi positif dalam pelaksanaan akuntanbilitas penyelenggaraan ataupun akuntanbilitas publik pemerintahan desa.
\end{abstract}

Kata kunci: regulasi, keuangan desa.

\section{A. Pendahuluan}

\section{Latar Belakang Permasalahan}

Desa memiliki kedudukan yang sangat strategis dalam sistem pemerintahan Indonesia mengingat bahwa desa merupakan satuan pemerintahan terkecil yang memiliki peranan fundamental bagi negara. Pengertian desa sangat beragam, artinya sangat tergantung dari sudut mana melihat desa. Perspektif geografi misalnya, desa dimaknai sebagai tempat atau daerah, dimana penduduk berkumpul dan hidup bersama dan mereka dapat menggunakan lingkungan setempat untuk mempertahankan, melangsungkan dan mengembangkan kehidupannya. Suhartono memandang desa sebagai tempat dimana bermukim penduduk dengan peradaban yang dinilai lebih terbelakang ketimbang kota. Dijelaskan desa bercirikan bahasa ibu yang kental, tingkat pendidikan yang relative rendah, pencaharian umumnya dari sektor pertanian. Bahkan terdapat kesan bahwa pemahaman umum memandang desa sebagai tempat bermukim para petani (Suhartono 
2001).

Secara sosiologis, definisi desa digambarkan sebagai bentuk kesatuan masyarakat atau komunitas penduduk yang bertempat tinggal dalam suatu lingkungan yang saling mengenal. Corak kehidupan yang relatif homogen serta banyak bergantung pada alam, mempunyai sifat sederhana dengan ikatan sosial dan adat istiadat yang kuat (Soekanto Soerjono,1990). Perspektif antropologis melihat desa sebagai suatu kumpulan manusia atau komunitas dengan latar suatu lingkungan atau geografis tertentu yang memiliki corak kebiasaan, adat istiadat dan budaya dalam kehidupannya, adanya upaya eksistensi hidup dan nilai estetika yang dimiliki mendorong adanya perbedaan karakter dan corak budaya yang dimiliki antara satu desa dengan desa lainnya.

Secara historis desa merupakan embrio bagi terbentuknya masyarakat politik dan pemerintahan di Indonesia, jauh sebelum negara bangsa modern ini terbentuk, entitas sosial sejenis desa atau masyarakat adat dan lain sebagainya, telah menjadi institusi sosial yang mempunyai posisi sangat penting. Perspektif ekonomi memotret desa sebagai komunitas masyarakat yang memiliki modal produksi yang khas dan merupakan lumbung bahan mentah (raw material) dan sumber tenaga kerja (man power). Sedangkan perspektif yuridis-politis bahwa desa seringkali dipandang sebagai suatu pemerintahan terendah di Indonesia atau kesatuan masyarakat hukum yang mempunyai identitas, entitas yang berbedabeda dan memiliki batas-batas wilayah yang berwenang untuk mengatur dan mengurus kepentingan masyarakat setempat, berdasarkan asal-usul dan adat istiadat setempat yang diakui dan dihormati dalam sistem pemerintahan NKRI.

Sesuai dengan pemikiran dan konteks empirik yang berkembang di Indonesia, setidaknya ada tiga tipe bentuk Desa (Direktorat Pemerintahan Desa dan Kelurahan Direktorat Jenderal Pemberdayaan Masyarakat Dan Desa Departemen Dalam Negeri, 2007):

1) Tipe "desa adat" atau sebagai self governing community sebagai bentuk Desa asli dan tertua di Indonesia.

2) Tipe "desa administratif" (local state government) adalah Desa sebagai satuan wilayah administratif yang berposisi sebagai kepanjangan negara dan hanya menjalankan tugas-tugas administratif yang diberikan negara.

3) Tipe "desa otonom" atau dulu disebut sebagai Desapraja atau dapat juga disebut sebagai local self government, seperti halnya posisi dan bentuk daerah otonom di Indonesia.

Desa mempunyai mempunyai otonomi yang disebut dengan otonomi desa dimana perlu ditegaskan bahwa otonomi desa bukan diberikan oleh negara tetapi otonomi desa berasal dari desa itu sendiri. Hal tersebut didasarkan pada sejarah ketatanegaraan Republik Indonesia dimana desa jauh lebih dulu terbentuk dari pada Negara Republik Indonesia. Tetapi hukum positif Indonesia yang mengatur tentang desa diantaranya Undang-Undang tentang Pemerintahan Daerah dan Undang-Undang tentang Desa menekankan bahwa negara yang memberikan otonomi kepada desa padahal otonomi tersebut memang sudah hidup dalam masyarakat desa bukan diberikan oleh negara. Dengan disahkannya UU Desa maka diprediksikan desa akan memasuki babak baru untuk penataan dan pembangunan wilayahnya (Yansen 2014), yang datang membawa harapan-harapan baru bagi kehidupan kemasyarakatan dan pemerintahan yang ada di desa (Ismail Widagdo, 2016).

Penerapan dan pelaksanaan otonomi desa diharapkan membawa semangat perubahan dalam mewujudkan tujuan pembangunan yaitu meningkatkan kesejahteraan masyarakat desa. Desa sebagai pemerintahan terkecil di Republik Indonesia sangatlah perlu untuk memiliki sistem yang mapan serta pentingnya melakukan penataan desa sebagai upaya mewujudkan pemerintahan desa yang efektif dan efisien. Adapun yang termasuk dalam ruang lingkup penataan desa adalah pembentukan, penghapusan, penggabungan, pendanaan, perubahan status dan penetapan desa. 
Adapun tujuan penataan desa seperti yang tertuang dalam Pasal 7 ayat (3) UndangUndang Nomor 6 Tahun 2014 tentang Desa adalah:
a. Mewujudkan efektivitas
penyelenggaraan Pemerintahan Desa;
b. Mempercepat peningkatan
kesejahteraan masyarakat Desa;
c. Mempercepat peningkatan kualitas pelayanan publik;
d. Meningkatkan kualitas tata kelola
Pemerintahan Desa; dan
e. Meningkatkan daya saing Desa.

Pembangunan daerah, kota dan desa adalah satu kesatuan dengan pembangunan nasional, dimana desa merupakan tempat tinggal sebagian besar masyarakat Indonesia. Oleh karena itu pembangunan desa mempunyai peranan yang penting dalam pelaksanaan pembangunan yang berdasarkan pada trilogi pembangunan yaitu pemerataan pembangunan dan hasil-hasilnya menuju kepada terciptanya keadilan sosial bagi seluruh rakyat, pertumbuhan ekonomi yang cukup tinggi dan stabilitas nasional yang sehat dan dinamis (Sri Woelan Azis, 1996).

Undang-Undang Nomor 23 Tahun 2014 tentang Pemerintahan Daerah mengamanatkan bahwa dalam pemerintah kabupaten dapat dibentuk desa yang termuat dalam Pasal 371 ayat (1) Undang-Undang Nomor 23 Tahun 2014 tentang Pemerintahan Daerah. Dimana Desa memiliki kewenangan sesuai dengan ketentuan perundangundangan mengenai desa.

Keberadaan desa sebagai satu kesatuan masyarakat hukum memberi pemahaman yang mendalam bahwa institusi desa bukan hanya sebagai entitas administratif belaka tetapi juga entitas hukum yang harus dihargai, diistimewakan, dilindungi dalam struktur pemerintahan di Indonesia. Disahkannya Undang-Undang Republik Indonesia Nomor 6 Tahun 2014 tentang desa menjadi keberlanjutan perkembangan desentralisasi di Indonesia. Undang-undang ini menempatkan desa memiliki otonominya sendiri (Muhamad Wahib Abdi Hendri Cahyono, 2015).

Otonomi Desa mengandung tiga makna: (a) hak desa untuk mempunyai, mengelola atau memperoleh sumberdaya ekonomi-politik; (b) kewenangan untuk mengatur atau mengambil keputusan atas pengelolaan barang-barang publik dan kepentingan masyarakat setempat; dan (c) tanggung jawab desa untuk mengurus kepentingan publik (rakyat) desa melalui pelayanan publik. (Direktorat Pemerintahan Desa dan Kelurahan Direktorat Jenderal Pemberdayaan Masyarakat Dan Desa Departemen Dalam Negeri, 2007).

Pemerintahan desa merupakan bagian yang terintegrasi dengan pemerintahan daerah. Bagaimana tidak, daerah baik kabupaten/kota dan juga provinsi terdiri dari kumpulan desa-desa hingga membentuk pemerintahan yang lebih tinggi diatasnya (Wafia Silvia Dhesinta, 2014).

Eko Sutoro mengemukakan isu-isu utama dalam pemerintahan desa pada umumnya adalah: (Eko Suroto, 2008)

1. Kedudukan dan kewenangan desa;

2. Perencanaan pembangunan desa;

3. Keuangan desa;

4. Demokrasi desa, khususanya akuntabilitas kepala desa serta posisi dan peran Badan Permusyawaratan Desa (BPD);

5. Birokrasi desa (Sekdes, sistem kepegawaian, penggajian, kesejahteraan, dan lain-lain.

Kewenangan yang besar yang dimiliki oleh desa serta pengelolaan atas keuangan desa menimbulkan banyak peluang permasalahan kedepannya termasuk terkait dengan regulasi keuangan desa.

\section{Metode Penelitian}

Penelitian ini menggunakan pendekatan yuridis-normatif dengan menggunakan metode analisis UndangUndang tentang Desa yang akan mampu menggambarkan regulasi terkait dengan keuangan desa (Suratman \& Philip Dillah, 2013). Pendekatan masalah yang digunakan untuk menjawab permasalahan ini adalah menggunakan pendekatan case of study (studi kasus) yaitu mengkaji pengaturan yang berkaitan dengan keuangan desa (Bahder 
Johan Nasution, 2008).

Melakukan studi kepustakaan dengan cara membaca, mengutip, menyalin dan menganalisa. Analisis data dilakukan secara kualitatif, komprehensif, dan lengkap. Data yang telah diperoleh akan dianalisis dengan mengggunakan interpretasi dan konstruksi hukum (Suratman \& Philip Dillah, 2013). Dengan melakukan interpretasi hukum, akan dilakukan penafsiran hukum melalui penemuan hukum (rechtsvinding). Kemudian, konstruksi hukum yang dilakukan melalui argumentasi hukum a contrario akan menjawab isu hukum. Sehingga, dengan metode penemuan hukum tersebut akan dihasilkan argumentasi hukum yang dapat menjawab isu hukum melalui penalaran hukum logis dan sistematis. Dan di akhir tulisan ini akan mampu untuk menunjukan bahwa regulasi keuangan desa yang ada di Indonesia berdasarkan hukum positif terkait dengan desa.

\section{B. Hasil dan Pembahasan \\ 1. Teori Keuangan Desa}

Keuangan berasal dari terjemahan kata monetary atau moneter, sedangkan kata finance mempunyai arti pembiayaan. Sementara itu, istilah keuangan Negara biasa dikaitkan dengan public finance. Finance atau pembiayaan adalah kegiatan yang berkaitan dengan uang. Prof Padmo Wahyono memberikan pengertian keuangan negara yaitu APBN “plus" dikatakan bahwa:

"APBN adalah anggaran pendapatan dan belanjanya pemerintah pusat. kekayaan Negara yang dipisahkan untuk mendirikan perusahaan milik Negara bukanlah pengeluaran konsumtif melainkan pengeluaran produktif yang diusahakan untuk menjadi sumber pendapatan baru bagi $A P B N$. Dengan perkataan lain, meskipun dipisahkan dari APBN, namun dalam waktu tertentu dan secara berangsur-angsur diharapkan dapat 'bergabung' kembali. APBN diadakan berdasarkan atas kuasa undangundang yang membagi wilayah Negara kesatuan kita menjadi daerah-daerah otonom. Demikian juga kedudukan perusahaan daerah terhadap APBD adalah serupa dengan kedudukan perusahaan milik pusat terhadap $A P B N$ "

Jimly Assiddiqie berpendapat keuangan daerah sebenarnya adalah juga keuangan Negara (Jimly Asshiddiqie, 2008).

Desa sebagai kesatuan pemerintahan terkecil dalam pemerintahan Indonesia memiliki sistem keuangan tersendiri yang terintegral kedalam pendapatan asli desa dan merupakan bagian dari APBN.

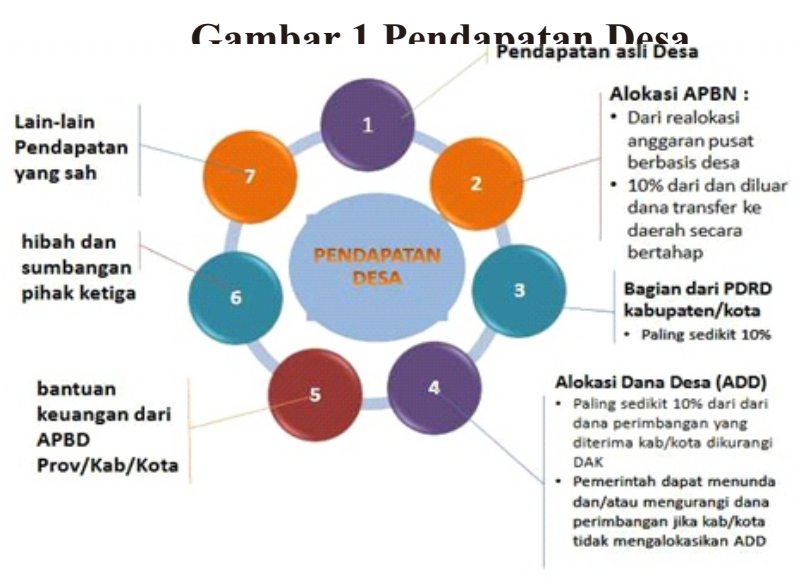

Berdasarkan gambar di atas menggambarkan bahwa pendapatan desa terbagi menjadi tujuh

bagian diantaranya:

1. Pendapatan Asli Desa;

2. Alokasi APBN;

3. Bagian dari PDRD Kabupaten/kota;

4. Alokasi Dana Desa (ADD);

5. Bantuan Keuangan dari APBN

Provinsi/Kabupaten/kota;

6. Hibah dan sumbangan pihak ketiga;

7. Lain-lain pendapatan yang sah.

Dari ketujuh poin diatas, Dana Desa (DD) memiliki posisi yang sangat strategis bagi pendapatan desa. Berdasarkan data dari Kementerian Keuangan Republik Indonesia, Dana Desa paling banyak digunakan untuk pembangunan desa, selanjutnya diikuti oleh pemberdayaan, pemerintahan, dan kemasyarakatan. Berikut ini adalah data Realisasi Penyaluran dan Penggunaan Dana Desa Tahun 2015 dan 2016 Secara Nasional. 


\section{Gambar 2. Realisasi Dana Desa}

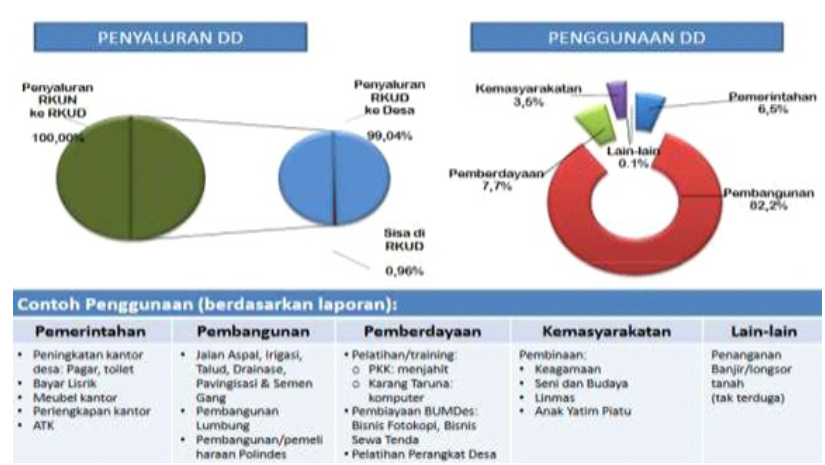

Gambar 3.

\section{Penyaluran dan Penggunaaan Dana Desa}
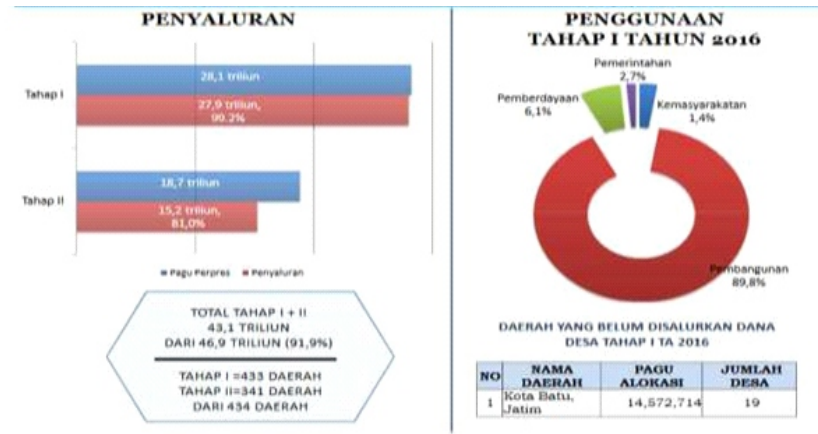

Keuangan desa, awal pengaturannya melalui Peraturan Menteri dalam Negeri No. 113 Tahun 2014 tentang Pengelolaan Keuangan Desa. Permendagri tersebut bertujuan untuk memudahkan dalam pelaksanaan pengelolaan keuangan desa, sehingga tidak menimbulkan multitafsir dalam penerapannya. Dengan demikian desa dapat mewujudkan pengelolaan keuangan yang efektif dan efisien. Disamping itu diharapkan dapat diwujudkan tata kelola pemerintahan desa yang baik, yang memiliki tiga pilar utama yaitu transparansi, akuntabilitas dan partisipatif. Oleh karenanya, proses dan mekanisme penyusunan APBDesa yang diatur dalam Permendagri tersebut akan menjelaskan siapa yang bertanggungjawab, dan kepada siapa bertanggungjawab, dan bagaimana cara pertanggungjawabannya.

Untuk itu perlu ditetapkan pedoman umum tata cara pelaporan dan pertanggungjawaban penyelenggaraan pemerintah desa, yang dimuat dalam Peraturan Menteri Dalam Negeri No. 35 Tahun 2007. Dalam perjalanannya seiring dengan perkembangan otonomi desa maka pengaturan keuangan desa mengalami perubahan.

\section{Tahapan Pengelolaan Keuangan Desa}

Pengertian keuangan desa menurut Undang-Undang Nomor 6 Tahun 2014 tentang Desa adalah semua hak dan kewajiban desa yang dapat dinilai dengan uang serta segala sesuatu berupa uang dan barang yang berhubungan dengan pelaksanaan hak dan kewajiban desa.

Berikut ini adalah gambar 4 yang menunjukkan siklus Pengelolaan Keuangan Desa. Setiap tahapan proses pengelolaan keuangan desa tersebut memiliki aturan aturan yang harus dipahami dan dilaksanakan sesuai dengan batasan waktuyang telah ditentukan (Kementerian Keuangan Republik Indonesia, 2016).

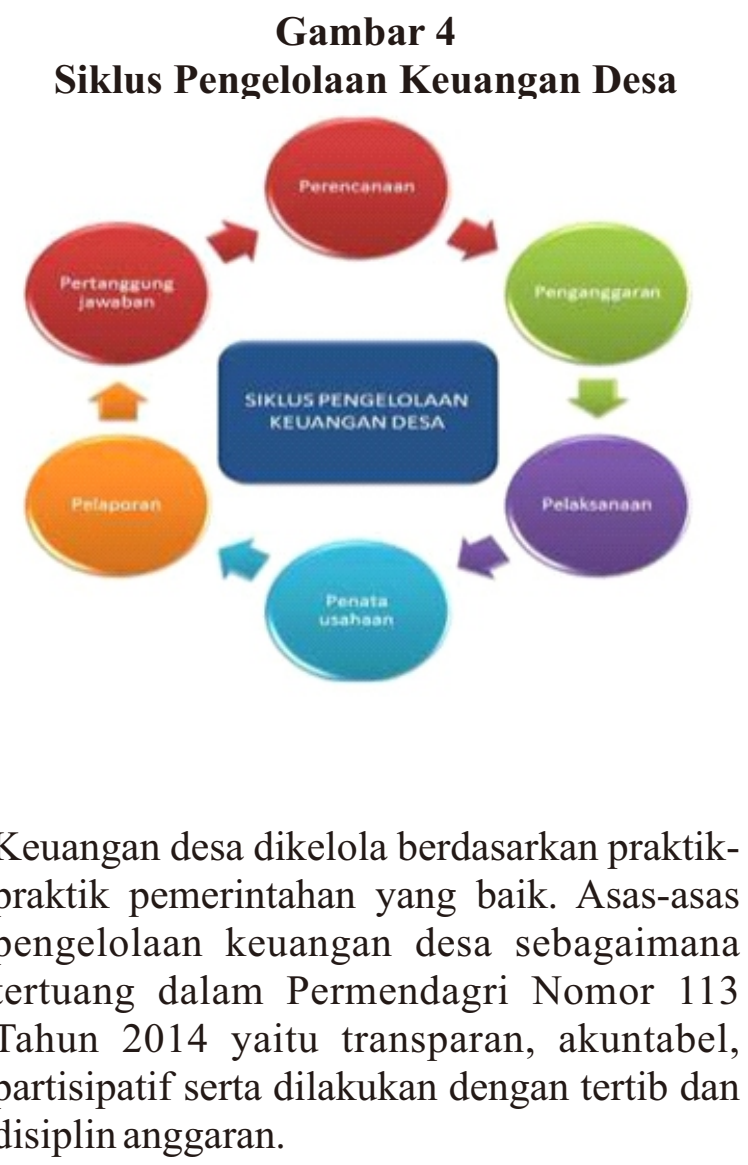


Pengelolaan keuangan desa dalam Undang-Undang Nomor 6 Tahun 2014 tentang Desa dan peraturan pelaksananya, kepala desa adalah pemegang kekuasaan pengelolaan keuangan desa. Dalam melaksanakan kekuasaannya, kepala desa menguasakan sebagian kekuasaannya kepada perangkat desa Pasal 75 ayat (2). Pengelolaan keuangan desa berdasarkan Pasal 93 ayat

(1) PP Nomor 43 Tahun 2014 tentang Peraturan Pelaksana Undang-Undang Nomor 6 Tahun 2014 tentang Desa meliputi Perencanaan, Pelaksanaan, Penatausahaan, Pelaporan dan Pertanggungjawaban.

\section{Pengawasan Pembangunan Desa}

UU Desa meletakkan prinsip dasar untuk penyelenggaraan, pengawasan dan pemantauan pembangunan desa yang meliputi pengawasan oleh supra-desa (downward accountability), pengawasan oleh lembaga desa dan pengawasan dari masyarakat (upward accountability). Terdapat beberapa mekanisme pengawasan dan pemantuan sebagai berikut (Buku Laporan Hasil Kajian Pengelolaan Keuangan Desa, 2015):

(i) Pengawasan oleh supra desa secara berjenjang oleh pemerintah kabupaten/kota dan oleh pemerintah pusat dalam hal ini Kementerian Dalam Negeri RI, Kementerian Desa RI dan Kementerian Keuangan RI (Pasal 26 PP No. 60 Tahun 2014). Dalam operasionalnya, pengawasan oleh pemerintah kabupaten/kota menjadi tanggung jawab bupati/walikota. Fungsi pengawasan tersebut didelegasikan oleh bupati/kota kepada camat dan juga Inspektorat Kabupaten/Kota. Hasil pengawasan Pemerintah Kabupaten/Kota disampaikan kepada Pemerintah Pusat terkait dengan unsur pengawasannya. Pengawasan dana Desa disampaikan kepada Kementerian Keuangan, pengawasan pembangunan Desa disampaikan kepada Kementerian Desa dan pengawasan pemerintahan disampaikan kepada Kementerian

\section{Dalam Negeri.}

(ii) Pengawasan supra Desa lainnya adalah pengawasan dari Badan Pemeriksa Keuangan (BPK) dan Badan Pengawasan Keuangan dan Pembangunan (BPKP). Hal ini didasari oleh UU No. 15 tahun 2004 tentang Pemeriksaan Pengelolaan dan Tanggung Jawab Keuangan Negara dimana keuangan desa yang berasal dari pemerintah pusat dan pemerintah daerah termasuk kedalam kategori keuangan negara karena sumbernya APBN dan APBD. PP No. 60 Tahun 2008 tentang Sistem Pengendalian Intern Pemerintah juga memberikan kewenangan bagi BPKP untuk mengawasi pengelolaan keuangan desa karena sumbernya yang berasal dari APBN maupun APBD.

(iii) Pengawasan oleh lembaga BPD sebagai bagian dari fungsi pengawasan terhadap kinerja Kepala Desa antara lain melalui tanggapan atas pertanggungjawaban Kepala Desa dan pengaduan masyarakat yang disampaikan melalui BPD (Pasal 55 dan 82 UU Desa). Seperti halnya fungsi DPR dan DPRD, BPD juga memiliki fungsi pengawasan terhadap perangkat desa dalam mengelola keuangan desa.

(iv) Pengawasan oleh masyarakat yang dijamin haknya untuk memantau dan $\mathrm{m}$ e $\mathrm{n}$ a $\mathrm{n}$ g a $\mathrm{p}$ i 1 a $\mathrm{p}$ or a $n$ pertanggungjawaban kepala desa (Pasal 82 UU Desa). Pengawasan masyarakat kepada perangkat desa dalam mengelola keuangan desa didukung dengan kewajiban bagi desa untuk memiliki sistem informasi desa sebagai pelaksanaan ketentuan hak masyarakat untuk mendapatkan informasi (Pasal 26, 55, 82 UU Desa).

Selanjutnya Undang-Undang tentang Desa mengamanatkan pembentukan peraturan yang lebih terperinci mengenai tata cara pelaksanaannya melalui peraturan pemerintah dan peraturan di tingkat menteri termasuk menyangkut sanksi jika terjadi pelanggaran atau pelaksanaan yang tidak 
sejalan dengan prinsip dan tujuan pembangunan desa.

Pengawasan memegang peranan penting dalam memastikan agar pengelolaan dana desa berjalan dengan akuntabel, transparan, dan partisipatif demi kemaslahatan umum masyarakat desa. Pengawasan yang ketat, terkontrol, profesional, dan berintegritas menjadi prasyarat penting (Antonius Galih Prasetyo \& Abdul Muis, 2015).

Pemberlakuan Undang-Undang Desa menetapkan entitas desa sebagai entitas pelaporan. Entitas desa memiliki kewenangan yang lebih besar dalam hal belanja termasuk kewenangan untuk membentuk badan usaha Desa (Junaidi 2015). Pengelolaan dana Desa dalam banyakpengaturan disebutkan bahwa pengelolaan keuangan desa adalah serangkaian kegiatan yang meliputi perencanaan, pelaksanaan, penatausahaan, pelaporan dan pertanggungjawaban (Sujamto ,1987).

Keuangan desa merupakan hierarki struktur keuangan sentral dari pemerintahan di atasnya. Kabupaten, propinsi, dan pemerintah pusat mempunyai andil besar dalam pengalokasian sumber keuangan desa. Dalam Undang-Undang Nomor 6 Tahun 2014 tentang Desa dikemukakan struktur pendapatan Desa yang terdiri atas pendapatan asli desa, bantuan dari pemerintah kabupaten, bantuan dari pemerintah pusat dan pemerintah propinsi, sumbangan dari pihak ketiga, dan pinjaman Desa (Sumbu, Telly, 2010).

Keuangan desa diatur dalam Pasal 71-75 Undang-Undang Desa. Pasal 71 ayat (1),dinyatakan bahwa "keuangan desa adalah semua hak dan kewajiban desa yang dapat dinilai dengan uang serta segala sesuatu berupa uang dan barang yang berhubungan dengan pelaksanaan hak dan kewajiban desa." Selanjutnya, pengaturan mengenai keuangan desa dan hal lain yang terkait dengannya dijabarkan lebih lanjut dalam berbagai peraturan, di antaranya:

1. PP No. 43 Tahun 2014 tentang Peraturan Pelaksanaan UU No. 6 Tahun 2014 tentang Desa;
2. PP No. 60 Tahun 2014 sebagaimana telah dirubah dengan PP No. 22 Tahun 2015 dan Peraturan Pemerintah Nomor 8 Tahun 2016 tentang Dana Desa yang Bersumber dari APBN;

3. PP No. 47 Tahun 2015 tentang Perubahan atas PP No. 43 Tahun 2014;

4. Permendagri Nomor 113 Tahun 2014 tentang Pengelolaan Keuangan Desa;

5. Permenkeu No.241/PMK.07/2014 tentang Pelaksanaan dan Pertanggungjawaban Transfer ke Daerah dan Dana Desa;

6. Permenkeu No. 250/PMK.07/-2014 tentang Pengalokasian Transfer ke Daerah dan Dana Desa;

7. Permenkeu No.93/PMK.07/2015 tentang Tata Cara Pengalokasian, Penyaluran, Penggunaan, Pemantauan, dan Evaluasi Dana Desa sebagaimana telah diganti dengan Peraturan Menteri Keuangan Nomor 49/ PMK 0.7/2016 tentang Tata Cara Pengalokasian, Penyaluran, Penggunaan, Pemantauan, dan Evaluasi Dana Desa, dan;

8. Permendes PDTT No. 5 Tahun 2015 tentang Prioritas Penggunaan Dana Desa dalam pengelolaan keuangan desa 2017 sebagaimana telah dirubah dengan Permendes PDTT Nomor. 22 Tahun 2016 tentang Prioritas Penggunaan Dana Desa 2017 dimana dalam Permendesa tersebut disebutkan secara rinci tentang program/kegiatan yang dapat didanai oleh Alokasi Dana Desa yang bersumber dari APBN dengan 2 pengelompokan besar yaitu dibidang Pembangunan Desa dan Pemberdayaan Masyarakat Desa.

Pengelolaan keuangan desa dimulai dari perencanaan. Pertama kali diadakan musyawarah desa yang diselenggarakan oleh Badan Permusyawaratan Desa (BPD) untuk membahas hal-hal yang sifatnya strategis (lihat Pasal 54 UU Desa). Kemudian, hasil musyawarah desa berupa perencanaan pembangunan desa ditindaklanjuti dengan musyawarah pembangunan perencanaan desa (musrenbangdes) yang diselenggarakan kepala desa dan perangkatnya. 
Musrenbangdes inilah yang membahas mengenai Rencana Pembangunan Jangka Menengah Desa (RPJMDes) tiap enam tahun sekali dan Rencana Kerja Pemerintah Desa (RKPDes) serta APBDes tiap setahun sekali.

Setelah Raperdes tentang APBDes disepakati bersama oleh kepala desa dan BPD paling lambat bulan Oktober dan hasil evaluasi dari bupati/walikota atau camat (yang mendapat delegasi untuk mengevaluasi Raperdes APBDes) menyatakan bahwa Raperdes APBDes tidak bertentangan dengan kepentingan umum dan peraturan perundangundangan yang lebih tinggi, APBDes dapat ditetapkan. Penggunaan dana desa dikelola oleh pemerintah desa melalui kuasa kepala desa dan digunakan sesuai RPJMDes, RKPDes, dan APBDes.

Adapun laporan realisasi pelaksanaan APBDes disampaikan kepala desa kepada bupati/walikota berupa laporan semester pertama yang harus disampaikan paling lambat akhir bulan Juli dan laporan semester akhir tahun paling lambat pada akhir bulan Januari tahun berikutnya (Pasal 37 Permendagri No. 113 Tahun 2014). Selain pelaporan, kepala Desa juga harus menyampaikan laporan pertanggungjawaban realisasi pelaksanaan APBDes dalam bentuk peraturan desa kepada bupati/walikota setiap akhir tahun anggaran (Pasal 38 Permendagri No. 113 Tahun 2014).

Dana Alokasi Desa yang diserahkan haruslah sesuai dengan karakteristik desa yang bersangkutan. Desa yang mempunyai wilayah luas dengan struktur perangkat desa yang banyak harus mendapatkan porsi dana alokasi lebih besar dari desa yang mempunyai karakteristik wilayah sempit dengan struktur perangkat desa yang sedikit. Oleh karena itu, perlu adanyaidentifikasi karakteristik wilayah desa sebelum menggunakan konsep dana alokasi desa, agartidak terjadi kesa-lahan besaran proporsidana alokasi Desa.

Pasal 2 Peraturan Pemerintah Republik Indonesia Nomor 60 Tahun 2014 Tentang DanaDesa Yang Bersumber Dari Anggaran Pendapatan Dan Belanja Negara yang telah mengalami perubahan sehingga menjadi PP No 22 Tahun 2015 jo PP 8/2016 tentang
Perubahan Kedua atas PP 60/2014 disebutkan bahwa dana desa dikelola secara tertib, taat pada ketentuan peraturan perundang-undangan, efisien, ekonomis, efektif, transparan, dan bertanggung jawab dengan memperhatikan rasa keadilan dan kepatutan serta mengutamakan kepentingan masyarakat setempat.

PermenDesa PDTTran Nomor 22 Tahun 2016 tentang Penetapan Prioritas Penggunaan Dana Desa Tahun 20017 sebagaimana telah dirubah dengan Peraturan Menteri D e $\mathrm{s} a$, Pembangunan Daerah Tertinggal, Dan Transmigrasi Republik Indonesia Nomor 4 Tahun 2017 Tentang Perubahan Atas Peraturan Menteri Desa,Pembangunan Daerah Tertinggal, DanTransmigrasi Nomor 22 Tahun 2016 Tentang P e n e tapan Prioritas Penggunaan Dana Desa

Tahun 2017 Pasal 4 disebutkan bahwa:

(1) Prioritas Penggunaan Dana Desa untuk membiayai pelaksanaan program dan kegiatan di bidang Pembangunan Desa dan Pemberdayaan Masyarakat Desa.

(2) Priroritas penggunaan dana Desa diutamakan untuk membiayai pelaksanaan program dan kegiatan yang bersifat lintas bidang.

(3) Program dan kegiatan sebagaimana dimaksud pada ayat (2) terutama bidang kegiatan BUMDesa atau BUMDesa Bersama, embung, produk unggulan Desa atau kawasan perdesaan dan sarana olahraga Desa.

(4) Prioritas penggunaaan dana Desa sebagaimana dimaksud pada ayat (1), dipublikasikan kepada masyarakat oleh Pemerintah Desa di ruang publik atau ruang yang dapat diakses masyarakat Desa.

Selanjutnya dalam Pasal 9 Permen Desa PDTTran Nomor 4 Tahun 2017 menyebutkan bahwa mekanisme penetapan prioritas penggunaan dana desa adalah bagian dari perencanaan pembangunan desa yang tidak terpisah dari prioritas pembangunan nasional. 


\section{Simpulan}

Indonesia telah memiliki regulasi yang sudah cukup signifikan terkait dana desa diantaranya: Undang- Undang Desa, dan delapan peraturan lain yang terkait langsung dengandana desa. Bukan hanya itu, peraturan-peraturan tersebut juga mengatur terkait dengan sistempengawasan pengelolaan dana desa. Pengelolaan keuangan desa sesungguhnya diawasi secaraberlapis oleh banyak pihak yakni Inspektorat Daerah akan berperan penting sebagai leadinginstitution pengawasan pengelolaan keuangan desa. Sementara di tingkat pusat, BPK dan BadanPengawasan Keuangan dan Pembangunan (BPKP) juga akan mengawasi pengelolaan keuangandesa secara sampling. Dana desa menjadi ranah pengawasan mereka dikarenakan dana desa adalah uang negara yang bersumber dari APBN sehingga pengelolaannya harus dipertanggungjawabkan sesuai dengan kaidah yang berlaku. Untuk memantau pelaksanaanpembinaan dan pengawasan dana desa, pemerintah pusat juga telah membentuk tim pengendali dana desa yang beranggotakan pejabat lintas kementerian.

\section{DAFTAR PUSTAKA}

Antonius Galih Prasetyo \& Abdul Muis (2015). Pengelolaan Keuangan Desa Pasca UU No. 6 Tahun 2014 Tentang Desa: Potensi Permasalahan Dan Solusi, Jurnal Desentralisasi Volume 13, No.1.

Asshiddiqie, Jimly (2008). Pokok-Pokok Hukum Tata Negara Indonesia Pasca Reformasi. Jakarta: PT Bhuana Ilmu Populer.

Syafrudin Ateng\& Suprin Na'a (2001). Republik Desa: Pergulatan Hukum Tradisional dan Hukum Modern dalam Desai Otonomi Desa. Bandung: Penerbit PT. Alumni.

Atmadja, Arifin P Soeria (2010). Keuangan Publik dalam Perspektif Hukum Teori, Praktik dan Kritik. Jakarta: Rajawali Pers.

Aziz, Sri Woelan (1996). Aspek-Aspek
Hukum Ekonomi Pembangunan di Indonesia, Surabaya:

Citra Media.

Buku Laporan Hasil Kajian Pengelolaan Keuangan Desa (2015). Alokasi Dana Desa dan Dana Desa, Komisi Pemberantasan Korupsi.

Direktorat Pemerintahan Desa dan Kelurahan Direktorat Jenderal Pemberdayaan Masyarakat Dan Desa Departemen Dalam Negeri (2007). Naskah Akademik Rancangan Undang-Undang Tentang Desa, Jakarta.

Eko, Sutoro (2008). Posisi Desa Dalam Otonomi Daerah. Yogyakarta: IRE Yogyakarta \& STPMD “APMD”.

Furqaini, A. (2009).Pengelolaan Keuangan Desa dalam Mewujudkan Good Governance (Studi pada Pemerintahan Desa Kalimo'ok Kecamatan Kali-anget Kabupaten umenep). Tesis. Program S2 Universitas Pembangunan Nasional"Veteran". Surabaya.

Ismail, Muhammad., Widagdo, Ari Kuncara., Widodo, Agus. (2016). Sistem Akutansi Pengelolaan Dana Desa. Jurnal Ekonomi dan Bisnis. Volume XIX No. 2, Agustus 2016, p. 323-340

Junaidi (2015). Perlakuan Akuntansi Sektor Publik Desa Di Indonesia, Jurnal NeOBis Volume 9, No. 1, Juni.

Muhammad, Abdulkadir (2004). Hukum dan Penelitian Hukum. Bandung: PT Citra Aditya Bakti.

Muhammad Wahib Abdi \& Hendri Cahyono, Jurnal Online Universitas Negeri Surabaya Volume 3 No3 Tahun 2015; Analisis Kesiapan Desa Blawi Dalam Rangka Implementasi Undang-Undang Republik Indonesia Nomor 6 Tahun 2014 Tentang Desa.

Nasution, Bahder Johan (2008). Metode Penelitian Ilmu Hukum. Jakarta: Mandar Maju.

P.A, Antono Herry (2015). Kesiapan Desa Menghadapi Implementasi UndangUndang Desa (Tinjauan Desentralisasi Fiskal dan Peningkatan Potensi Desa), Jurnal Ilmiah CIVIS, Volume V, No 1, Januari.

Saparin (1979). Tata Pemerintahan dan Administrasi Pemerintahan Desa. 
Jakarta: Ghalia Indonesia.

Soekanto, Soerjono (1990). Sosiologi Suatu Pengantar. Edisi 12. Jakarta: Rajawali Press.

Soerjono Soekanto \& Sri Mamudji (2011). Penelitian Hukum Normatif Suatu Tinjauan Singkat. Jakarta: PT Raja Grafindo Persada.

Suhartono (2001). Politik Lokal, Parlemen Desa : Awal Kemerdekaan Sampai Jaman Otonomi Daerah. Yogyakarta: Lapera Pustaka Utama.

Sujamto (1987). Aspek-Aspek Pengawasan di Indonesia. Jakarta: Sinar Grafika.

Sumbu, Telly (2010) Hubungan Pemerintah Pusat dengan Pemerintah Daerah dalam Kerangka Pengelolaan Keuangan Negara dan Daerah, Jurnal Hukum No. 4 Vol. 17 Oktober.

Sunggono, Bambang (1997). Metode Penelitian Hukum. Jakarta: Raja Grafindo Persada.

Suratman \& H. Philips Dillah (2013). Metode Penelitian Hukum. Bandung: Alfabeta.

Tim Penyusun Kamus Pusat Pembinaan dan Pengembangan Bahasa (1995). Kamus Besar Bahasa Indonesia. Jakarta: Departemen Pendidikan dan Kebudayaan bekerjasama dengan Balai Pustaka, Edisi Kedua, Cet. VII.

Wafia Silvia Dhesinta \& Annisa Putri Andini (2015). Analisis Yuridis Mekanisme Pengelolaan Keuangan Desa Berdasarkan Undang-Undang Nomor 6 Tahun 2014 Tentang Desa Guna Terwujudnya Pembangunan Desa. Yogyakarta: Fakultas Hukum, Universitas Gajah Mada.

Wibawa, I gede Agus (2011). Pengaruh Status Kelurahan Menjadi Desa Dalam Persektif Pemerintahan Daerah (Studi Kasus Perubahan Status Pemerintahan), Disertasi tidak diterbitkan, Program Pascasarjana FIA Universitas Brawijaya.

Yansen. (2014). Revolusi dari desa (saatnya dalam pembangunan percaya epenuhnya kepada akyat). Jakarta: PT Elex Media Komputindo

\section{Peraturan perundang-undangan}

Undang-Undang Nomor 6 Tahun 2014 tentang Desa (Lembaran Negara Republik Indonesia Tahun 2014 Nomor 7, Tambahan Lembaran Negara Republik Indonesia Nomor 5495).

Peraturan Pemerintah Republik Indonesia Nomor 43 Tahun 2014 tentang Peraturan Pelaksanaan UndangUndang Nomor 6 Tahun 2014 tentang Desa (Lembaran Negara Republik Indonesia Tahun 2014 Nomor 123, Tambahan Lembaran Negara Republik Indonesia Nomor 5539) sebagaimana telah dirubah dengan Peraturan Pemerintah Republik Indonesia Nomor 47 Tahun 2015 tentang Perubahan atas Peraturan Pemerintah Republik 